\title{
Fronteiras móveis na definição do corpo
}

Norma Discini (USP)

Recebido 4 ago. 2013/Aprovado 25 abr. 2014

\section{Resumo}

Trataremos do sujeito discursivo, enunciador pressuposto aos enunciados por ele construídos, na medida em que esse sujeito, como estilo, é concebido a partir de um corpo, uma voz, um tom de voz e um caráter. Tal corpo será pensado especialmente como percepção, e esta, vista como semiose, será considerada emergente da relação expressão/conteúdo dos textos. Então dos textos despontará o sujeito que sente o mundo como impacto e emoção. Para isso, após uma reflexão a ser feita no âmbito da sintaxe discursiva, em que firmaremos pressupostos teóricos sobre a enunciação e o ato de fazer-ser o sentido, examinaremos as fronteiras na constituição do corpo do ator: $o$ sujeito enunciador firmado no papel de produtor de seus textos. Tais fronteiras serão contempladas na sua mobilidade, enquanto serão trazidos à luz mecanismos que promovem o esboroamento da ilusão referencial, principalmente no que diz respeito à fusão de temporalidades do enunciado $e$ da enunciação na constituição da categoria de pessoa. Essa mobilidade também será contemplada conforme um tempo-espaço da percepção, para o que serão examinados movimentos de abertura do espaço, de repouso do tempo e de distensão do corpo, o que se vincula à dinâmica estabelecida entre as tensões do que é contínuo e do que é descontinuo na percepção.

Palavras-chave: corpo; estilo; discurso; tensão. 


\section{O corpo do ator: entre a imanência e a transcendência}

A mobilidade das fronteiras na definição do corpo parte da correlação entre imanência e transcendência, conforme a semiótica de base greimasiana, uma teoria da significação que contempla a construção dos enunciados na relação entre a imanência (o que é interior aos textos) e a transcendência (o que é exterior a eles). Comecemos pela imanência que, equivalente ao plano do conteúdo dos textos, somente se compõe na relação com a própria transcendência. Lembramos então que a semiótica greimasiana considera o sentido construído na relação entre o plano da expressão e o plano do conteúdo dos textos, e o plano do conteúdo compartimentado em três níveis, o fundamental, o narrativo e o discursivo, cada qual apresentado segundo duas dimensões: uma sintática e uma semântica. Se, nos níveis fundamental e narrativo, são levadas em conta relações mais gerais da construção do sentido, no nível discursivo são considerados procedimentos vinculados à argumentação, o que supõe estratégias de persuasão e o que confirma a presença relacionada à assunção dos valores que vêm à luz no ato de enunciar. No discurso contemplamos, portanto, o enunciador, na medida em que o sujeito projeta-se nos enunciados como enunciação enunciada. Falamos da pessoa que, concernente à sintaxe discursiva, converte-se em ator, graças a dispositivos da semântica discursiva assentados na tematização e na figurativização.

O ator da enunciação apresenta-se mediante um esquema corporal, síntese dos mecanismos de construção do sentido apreensíveis dos enunciados. Para a descrição da arquitetura do corpo do enunciador, atentamos então para a sintaxe discursiva, que supõe relações conceituais, mais autônomas, se comparadas às relações semânticas, das quais decorrem os temas e as figuras. A sintaxe discursiva cuida das três categorias da enunciação - a pessoa, o tempo e o espaço- que, postas a serviço do discurso, organizam-se segundo sistemas: o pessoal, o espacial e o temporal.

A categoria de pessoa, como respaldo do ator da enunciação, recebe preenchimento semântico, na medida em que se concretizam peculiarmente as relações abstratas de sentido. Concretizar temática e figurativamente a liberdade, como, por exemplo, "calça velha, azul e desbotada" (FIORIN, 1988, p. 24), vincula-se a um posicionamento da enunciação em relação ao mundo feito enunciado, enquanto se desvela o lugar ocupado pelo sujeito entre aspirações e crenças relativas às formações sociais que atravessam o discurso. Tais movimentos, que ocorrem no nível discursivo, concernente ao plano do conteúdo dos textos (imanência), corroboram a imanência transcendente de si na direção do outro: uma imanência que, firmada nas relações estabelecidas no interior do plano do conteúdo dos textos, palpita, entretanto, de transcendência e de historicidade. 
As relações semânticas promovem preenchimentos variados das categorias de pessoa, espaço e tempo, que constituem a sintaxe discursiva. Para isso ancoram, por exemplo, a pessoa, em antropônimos, o espaço, em topônimos, o tempo, em cronônimos. Ao denominar espaços e atores por meio de nomes próprios, os topônimos e os antropônimos "participam do subcomponente onomástico da figurativização", como dizem Greimas e Courtés (2008, p. 33) e, ao lado de cronônimos como "jornada", "primavera", "passeio" ( p. 108), "permitem uma ancoragem histórica que visa a constituir o simulacro de um referente externo e a produzir o efeito de sentido 'realidade'" (p. 33).

O sujeito a ser contemplado na definição do próprio corpo não está circunscrito a uma denominação onomástica: não será visto como José, Maria, Pedro, mas como ator discursivo. $\mathrm{O}$ ator "é o lugar de convergência e de investimento dos dois componentes, sintático e semântico", como alertam Greimas e Courtés (2008, p. 45). Na sintaxe discursiva, o ator supõe uma "pessoa multiplicada" (FIORIN, 1996, p. 61) a princípio em enunciador, "primeiro nível da enunciação", e narrador, "segundo nível da hierarquia enunciativa" (FIORIN, 1996 , p. 65) - para que assim a enunciação se projete no enunciado. Assim, no que se refere ao componente semântico, o sujeito radica-se num papel temático. Um exemplo de papel temático é o de pescador, tal como estudado por Greimas na exploração feita de um conto voltado a dois sujeitos que se lançam numa pesca (GREIMAS, 1993). Aí o pescador, como ator do enunciado, grosso modo um personagem, reúne funções desempenhadas na performance correspondente ao ato de pescar.

Discursivizar uma pescaria convoca então a tematização do mundo a partir de conceitos relativos a essa prática e, eventualmente, convocará também determinada figurativização, que poderá particularizar aquela e única situação de pesca. Enquanto isso o pescador, ao definir-se no papel temático daquele que pesca, fundamenta-se no nível narrativo como sujeito de determinada performance. Nesse nível o sujeito "que pesca", considerado um papel actancial, é levado em conta no percurso da ação, um dos quais compõem a narratividade de qualquer texto. A narratividade subjacente a qualquer texto supõe três percursos (manipulação, performance, sanção), dos quais despontam distintas funções actanciais para o sujeito. A função ou o papel actancial, que é da ordem da abstração narrativa, ancora-se no discurso na categoria de pessoa, por sua vez preenchida semanticamente para tornar-se um ator. Desse circuito emerge o corpo: do ator do enunciado e do ator da enunciação. No enunciado, poderão aparecer antropônimos como João, José, Pedro, para confirmar na pessoa sua "carne" semântica, que diz respeito à "formulação actancial de temas" (GREIMAS; COURTÉS, 2008, p. 357). Entre João, José, Pedro, atores do enunciado, poderá estar determinado pescador. 
O ator, ou do enunciado, ou da enunciação, verdadeiramente carece de um papel temático e de um papel actancial. O último pode ser evocado seja como um destinador de valores (no percurso da manipulação), seja como um sujeito que se desempenha de modo próprio em determinada performance (no percurso da ação), entre outras possibilidades contidas no esquema narrativo canônico. Papéis temáticos, por sua vez, confirmados como "a formulação actancial de temas ou de percursos temáticos" (GREIMAS; COURTÉS, 2008, p. 357), apresentam uma função própria na composição do ator. Ao finalizar uma exposição sobre o que é um ator, afirmam os semioticistas:

Vê-se, portanto, aparecer, na superfície do texto, uma estrutura actorial que não é, no fundo, senão uma estrutura topológica, já que os diferentes atores do discurso são constituídos como uma rede de lugares que, vazios por natureza, são lugares de manifestação das estruturas narrativas e discursivas (GREIMAS; COURTÉS, 2008, p. 45).

Se considerarmos vazio, porque ainda abstrato, o lugar de um sujeito da ação (da performance), notamos que esse vazio é preenchido pelo papel temático desempenhado na ação trazida à luz por determinado discurso. Assim emerge o ator discursivo. Por sua vez, para examinarmos o sujeito da enunciação como ator, o papel temático que interessa é o de "produtor" dos próprios enunciados. $\mathrm{O}$ ator da enunciação, considerado como enunciação enunciada é concebido, portanto, como pessoa enunciativa, o eu pressuposto que, ao deixar-se apreender nos enunciados por ele produzidos, está em relação necessária com a pessoa, o tempo e o espaço, categorias que organizam tais enunciados. A partir daí, o mundo interpretado e percebido peculiarmente em cada situação discursiva entra na composição de um todo, que é o sujeito-no-mundo: um todo cujas partes se exigem reciprocamente (sujeito e mundo), por isso elas unem-se na grafia por meio do uso do hífen. Novamente diluem-se fronteiras.

Como um dos componentes da discursivização, a actorialização enunciativa supõe, juntamente com os mecanismos que instalam no enunciado o "eu" pressuposto, a tematização e a figurativização que preenchem semanticamente a pessoa. Considerada como um "actante da enunciação" (FIORIN, 1996, p. 60), a pessoa ratifica-se abeirada do "autor implícito", já que o autor real ou o sujeito em si é tido como inapreensível para os princípios discursivos. Ainda, examinada enquanto está despojada da "carne" semântica, a pessoa confirma-se "multiplicada" (FIORIN, 1996 , p. 61) conforme distintas instâncias enunciativas, como a do enunciador e a do narrador, cravadas no âmbito da enunciação enunciada. Se vista já encarnada por meio de papéis temáticos e nos seus investimentos figurativos, a pessoa confirma-se convertida em ator. 
Um lugar actancial próprio à função de destinador dos valores veiculados pelo discurso sustenta a pessoa discursiva que, encarnada como ator, convoca uma ancoragem histórica condizente com o procedimento de tematização e de figurativização. Afinal, por meio da semântica discursiva apresenta-se uma "maneira de ver o mundo numa dada formação social" (FIORIN, 1988, p. 19). No plano do discurso, a semântica, mais do que a sintaxe, seguramente traz à luz o sujeito aberto ao outro. Por isso se diz que as relações semânticas são menos autônomas do que as sintáticas. Mas essa autonomia não é absoluta.

Por meio do exame feito dos mecanismos de instauração da pessoa, do tempo e do espaço no discurso, somos lançados no tumulto das estratégias discursivas, que cuidam de criar efeitos de sentido como os de: objetividade ou subjetividade; referencialização ou desrreferencialização da pessoa que enuncia; proximidade ou distanciamento entre os parceiros da comunicação; outros. Tais movimentos, que cravam a enunciação no enunciado por meio daquelas categorias, enquanto se vinculam a estratégias argumentativas, aliam-se ao fazer persuasivo do enunciador no encontro com o fazer interpretativo do enunciatário, o que se relaciona com a intencionalidade discursiva. Enunciador (autor implícito) e enunciatário (leitor implícito) constituem o primeiro nível da enunciação, considerado como "quadro implícito e logicamente pressuposto pela própria existência do enunciado", como resume Fiorin (1996, p. 65). O segundo nível da enunciação pertence ao narrador e ao narratário, "sujeito diretamente delegados do enunciador e do enunciatário", como propõem Greimas e Courtés (2008, p. 327).

Importa que, na enunciação, tudo acontece a partir de um gesto fundador: o "ato" de fazer-ser o sentido. $\mathrm{O}$ ato de enunciar, que permeia as relações estabelecidas desde os níveis mais gerais e abstratos da geração do sentido, está no produto enunciado: o dizer decorre do dito, e, lá e cá, um princípio de sistematicidade viabiliza a emergência do corpo. Enquanto concebemos o enunciado como uma organização compatível com os princípios da estrutura e da imanência, vindos até nós por meio da herança hjelmsleviana (HJELMSLEV, 2003), confirmamos que não interessam à depreensão do corpo actorial objetos apriorísticos ao discurso ou relativos ao mundo "em si". Interessa, para tal fim, tão somente o que é decorrente de uma relação de dependências mútuas, como: enunciado/ enunciação; sujeito/ objeto; destinador/ destinatário; interior/ exterior; imanência/ transcendência, entre outras. Relação de dependências mútuas é conceito que remete à noção de estrutura, e esta, à noção de sistema. Levada em conta a sistematicidade do enunciado e da enunciação, deduzimos que o corpo do ator da enunciação é concebido como uma estrutura passível de descrição; porém uma estrutura aberta ao evento, que é o encontro sujeito-mundo. 
O mundo feito discurso pode apresentar-se dominantemente conforme sistemas de valoração social, os quais atravessam temas e figuras para que se defina o ator da enunciação conforme um posicionamento ético. Mas pode também apresentar-se dominantemente como o que afeta sensivelmente o sujeito, para que o corpo se mostre contingente e precário conforme a percepção desenvolvida no encontro sujeito-mundo, ocasião em que fronteiras ou linhas que definem a identidade do sujeito como corpo poderão ser diluídas e limites poderão ser borrados por conta de um sensível que rege o inteligível.

Como posicionamento ético, isto é, a favor de $x$, logo contra $y$, emergem decisões tomadas pelo sujeito para ocupar um lugar no mundo. Essas decisões articulam-se à argumentação e são sustentadas, no percurso gerativo do sentido, desde as operações de negação constantes do quadrado semiótico, as quais fundam a oposição entre o que é eufórico e desejável, de um lado, e o que é disfórico e indesejável, de outro. Uma oposição mantida supõe o descontínuo: ou $x$, ou $y$. Para isso concebe-se a foria segundo a bipartição tímica (euforia vs. disforia), o que reforça os contornos na definição ética do corpo. Determinados gêneros discursivos, como o artigo de opinião e o editorial, ambos da esfera jornalística, priorizam esse viés de observação. Sob outro viés, pode ser priorizada a presença sensível, e a foria será apresentada como elã ou força que leva adiante o sujeito na sua relação de afeto com o objeto-mundo-percebido. Nesse caso, pode aparecer uma inclinação do ator por um lugar de limiar, o que tornará mais diluídos os contornos do corpo ou os contornos entre o sujeito que percebe o mundo e o mundo percebido, postos ambos os correlatos sob as gradações do contínuo. Mas, para serem diluídas, as fronteiras existem. Confirmadas ou diluídas, elas estão até no princípio fundador da noção de enunciação, já que o sujeito concebido no ato de dizer apresenta-se apreensível a partir do que é dito. Para isso, o ato enunciativo firma-se como um gesto de disjunção.

\section{A enunciação enunciada: um ato de disjunção}

Para disjungir-se, a enunciação pressuposta debreia-se por meio das categorias segundo as quais ela se projeta no enunciado, conforme sistemas (temporal, espacial e de pessoa), articulados a partir do ego, hic e nunc, os pilares em que se assenta o "eu" tornado pessoa ao enunciar-se, conforme o princípio linguístico da subjetividade da linguagem (BENVENISTE, 1995). Tal ato de disjunção é assim comentado por Landowski (1997, p. 230):

Fundamentalmente, todo ato produtor de sentido, e mais especificamente todo ato de enunciação, é verdadeiramente uma disjunção. Ao enunciar, o sujeito falante separa-se involuntariamente, senão de si mesmo, pelo menos de seu "produto" - de seu próprio discurso. Qualquer que seja o modo de expressão (verbal ou outro) ao qual recorremos, desde o momento em 
que começamos a nos "exprimir", as formas, as palavras, os gestos, etc. - que empregamos [...] deixam de nos pertencer.

Fiorin (1996), ao demonstrar que as categorias enunciativas regem-se pelos mesmos princípios de organização, insiste no fato de que não estamos diante da pessoa, do tempo e do espaço reais, mas da pessoa, do tempo e do espaço "criados na e pela enunciação" (p. 301). Realça também que cada uma dessas categorias, como componente da discursivização, apresenta um sistema enunciativo e um enuncivo. $\mathrm{O}$ primeiro remete a uma relação direta com o eu, o aqui e o agora da enunciação; o segundo diz respeito ao não-eu, ele (actante do enunciado), ao não-aqui, algures, (espaço do enunciado), ao não-agora, então (tempo do enunciado). Porém o ele, o então e 0 algures somente têm valor na relação estabelecida com o ego, hic e nunc, conforme demonstrado no mesmo estudo. Esses movimentos, segundo os quais a pessoa põe-se em discurso à moda de uma disjunção de si, de acordo com o que disse Landowski (1997), ao fazerem da enunciação pressuposta uma enunciação enunciada, apresentam-se, desde o pensamento greimasiano, conforme uma debreagem.

Greimas e Courtés (2008, p. 112), ao alertar para a diferença entre actantes da enunciação e actantes do enunciado, lembram que a debreagem enunciativa leva a formas da enunciação enunciada, caso das "narrativas em 'eu'", como dizem (p. 112 . Fiorin (1996, p. 66) desenvolve esse tópico e alerta para a existência do eu-narrador, necessariamente implícito a qualquer enunciado e eventualmente explícito neles.

A debreagem enunciativa, segundo Greimas e Courtés (2008), inclui as sequências dialogadas desenvolvidas no interior dos textos, o que supõe uma debreagem enunciativa interna ou de segundo grau. Para a debreagem enunciva, Greimas e Courtés (2008) lembram "sujeitos quaisquer", tal como se apresentam nos "discursos chamados objetivos", ou sob "formas do discurso objetivado" (p. 112). No Dicionário I de semiótica, a obra referida (GREIMAS; COURTÉS, 2008), um hiato instala-se, entretanto, entre a delegação de vozes: do enunciador para o narrador, do narrador para o interlocutor, este último o actante do enunciado, sujeito que se apropria de um turno de fala por meio do discurso relatado na forma de discurso direto.

Fiorin, tal como destacado por ele mesmo (1996, p. 115), "alarga o conceito greimasiano de debreagem". Desse fato beneficia-se o estudo relativo à constituição do corpo do ator da enunciação, fundado em determinado modo de dizer. Certamente traz consequências pensarmos em que "não só a voz que enuncia está ligada à instância da enunciação, mas também as pessoas que designam os actantes da narrativa são indicadas em relação ao eu do narrador" ( FIORIN, 1996, p. 115). 
O modo de dar corpo ao ator do enunciado reverbera no corpo do ator da enunciação. Completa Fiorin (1996): “Como há um nível da narração (enunciação) e um do narrado (enunciado), devem-se distinguir as pessoas da enunciação e do enunciado." De nossa parte, entendemos que, se um narrador implícito desenvolve "apreciações moralizantes" (p. 66) sobre o mundo (feito enunciado), o mesmo narrador firma para o ator um corpo ético, discernível a partir dos mecanismos de construção do sentido.

Paralelamente ao desempenho de suas funções, o narrador, no âmbito da sintaxe discursiva, como segundo nível da hierarquia enunciativa, poderá ter os limites borrados em relação ao enunciador, primeiro nível da mesma hierarquia. Nesse caso, a partir de recursos da sintaxe discursiva, o corpo poderá mostrar-se com os contornos borrados e com uma mobilidade própria à percepção tida do mundo. $\mathrm{O}$ ator da enunciação, no papel temático de produtor de seus textos pode então privilegiar o tema do inacabamento do mundo ou de um mundo ao revés, o que poderá aliar-se a gestos afinados com fronteiras móveis na definição do corpo: gestos incompatíveis com o fechamento do espaço e com uma retenção da temporalidade constituinte do próprio corpo. Desse modo, fronteiras móveis podem constituir vetores de um estilo.

\section{As fronteiras móveis}

A competência discursiva do ator da enunciação goza de certa estabilidade para garantir a conformação de um corpo. Essa estabilidade radica-se nas funções actanciais. Despojados da semanticidade ou da "carne" discursiva, sujeito e objeto, destinador e destinatário, papéis actanciais relativos à narratividade que sustenta enunciado e enunciação, respaldam a competência discursiva do ator da enunciação, concretizado não muito diferentemente do que acontece com um sapateiro e sua competência ou seu saber-fazer sapatos. Dizem Greimas e Courtés (2008, p. 329) que "a atividade discursiva repousa sobre um saber-fazer discursivo, que nada perde para o saber-fazer de um sapateiro". Tais volteios que, relativos à competência pressuposta à performance não mais de um sapateiro, mas do produtor de enunciados, partem de uma disjunção do enunciador em relação a si, e acompanham ainda as estabilidades das categorias de pessoa, tempo, espaço, que projetam a enunciação no enunciado. Mas a partir das estabilidades emergem as instabilidades. Aqui reaparecem as fronteiras móveis na definição do corpo.

Na sintaxe discursiva, entre os recursos que dizem respeito às projeções da enunciação no enunciado e que refletem as relações entre enunciador e enunciatário, notamos que uma pessoa pode ser usada no lugar de outra, um tempo, no lugar de outro, uma localização espacial, no lugar de outra. Tais procedimentos ficam realçados por Fiorin (1996) como neutralização de uma categoria 
por outra com benefício de uma delas. Como exemplo, podemos lembrar o caso de Pelé que, ao falar de si, poderia afirmar: "Pelé é o rei do futebol", o que se configuraria como uma embreagem, esta compreendida como a própria neutralização da oposição entre o eu e o ele com benefício do ele. Como o ele é actante do enunciado, teríamos aí uma embreagem enunciva no trato com a pessoa discursiva, o que firmaria um efeito de persona ou de pessoa pública. Podemos também lembrar o caso do cliente bancário que, ao dirigir-se ao balcão do banco, poderia assim expressar-se: "Eu queria pagar isto", numa desestabilização do sistema do tempo: a expectativa aí era de que fosse usado um presente do sistema enunciativo (o presente relativo ao agora do ato enunciar - quero pagar isto). O uso feito do pretérito imperfeito, tempo que indica uma concomitância em relação a um marco pretérito, torna a fala do cliente mais distanciada do agora de sua enunciação, veiculando um efeito de atenuação do pedido. As instabilidades não são aleatórias. Organizadas para construir efeitos de sentido, tal como fica comprovado no mesmo estudo (cf. FIORIN, 1996 ), lançam-se a partir de uma zona de mobilidade entre as fronteiras internas ao sistema que funda a actorialização, a temporalização e a espacialização.

Das embreagens, saltamos para as macroembreagens e seu efeito de esboroamento da ilusão referencial como está demonstrado por Fiorin (1996) , quando o semioticista cuida da pessoa desdobrada ( p. 103-126). Ao retomar estudo feito por Barros (1988) sobre o mecanismo de delegação de vozes que articula distintos níveis enunciativos (enunciador, narrador, interlocutor, de um lado; enunciatário, narratário, interlocutário, de outro), sendo cada lado representante dos parceiros da comunicação, Fiorin (1996) realça a possibilidade de efetuarmos a passagem de um nível enunciativo a outro, enquanto "a ilusão referencial esboroa-se" (p. 122). O semioticista declara:

O narrador pode instalar-se na narrativa, quando, jogando com a temporalidade da narração e do narrado, preenche os "vazios" da história com explicações, como se a narração fosse concomitante aos acontecimentos.

Em Ilusões Perdidas, de Balzac, há a seguinte passagem:

Enquanto o venerável eclesiástico sobe as encostas de Angoulême, não será inútil explicar a trama de interesse em que vai meter os pés (FIORIN, 1996, p. 122).

Enquanto, nesse estudo, é trazido à luz o modo como se dá a mobilidade entre as fronteiras do narrado e da narração e o decorrente efeito de "meta-realidade, de liberação das rígidas convenções miméticas" (FIORIN, 1996, p. 122), fica sugerido para nós que a sintaxe discursiva pode respaldar contratos veridictórios que, estabelecidos entre enunciador e enunciatário (cf. GREIMAS, 
1983, p. 103 - 113), vinculam-se à natureza da verdade construída nos discursos.

As macroembreagens inauguram no discurso peculiaridades epistêmicas, isto é, relativas a um crer que sobredetermina o ser conforme a mobilidade de fronteiras. Para discorrer sobre uma "estrutura modal epistêmica", Greimas e Courtés (2008, p. 172) destacam o crer-ser oposto ao crer não ser. Mas a macroembragem anteriormente citada a partir do texto de Baudelaire por certo faz o discurso oscilar entre tais extremos. Aquela macroembreagem faz o discurso oscilar nas fronteiras móveis entre o crer-ser, que é da ordem da certeza, e o crer-não-ser, que é da ordem improbabilidade. Um lugar de limiar na configuração do corpo do ator da enunciação é projetado por meio da mobilidade das fronteiras entre o enunciador (autor implícito) e o narrador (sujeito instalado no enunciado). Estamos no domínio das ambiguidades, o que pode ser pensado a partir do que prevê Greimas (1983), ao discorrer sobre as condições de emergência de um "crer ambíguo" ( p. 112). Esse crer é apresentado como a "coincidência de contrários" ; ou como "o termo complexo que reúne a certeza e a improbabilidade" (GREIMAS, 1983, p. 112 ) e, assim, "concerne a dois contextos ideológicos incompatíveis e, finalmente, a duas epistemes coexistentes" ( p. 113). Enquanto realça a relatividade dos contratos veridictórios, Greimas (1983) lembra que, embora de estatutos diferentes, a verdade e a certeza, de coexistência difícil, porém inevitável, remetem a epistemes que recobrem culturas, o que se avizinha de distintas "linguagens de conotação" ( p. 113).

Ao esboroar o sistema de delegação de vozes para desdobrar a pessoa no discurso, provocando o efeito de mobilidade entre as fronteiras que definem os níveis enunciativos na projeção da enunciação no enunciado, o recurso de jogar com a temporalidade da narração e a do narrado certamente instaura um "crer ambíguo". Essa ambiguidade comprova, entre os parceiros da comunicação, a singularidade de um contrato de veridicção, que privilegia o limiar (e não os limites) entre a certeza e a improbabilidade. Desse modo, efeitos de verdade (algo parece $x$ e é $x$ ), de mentira (algo parece $\mathrm{x}$, mas não é $\mathrm{x}$ ), de segredo (algo é $\mathrm{x}$, mas não parece), de falsidade (algo nem parece $x$, nem é $x$ ) apresentam-se também relativizados. Tal relativização, por sua vez, emparelha-se à diluição de fronteiras na arquitetura das próprias certeza (crerser) e improbabilidade (crer não ser), modalidades que orientam a competência epistêmica do sujeito, assim direcionada a um mundo ao revés. Essa competência está relacionada a um "querer crer" e a um "poder crer", como lembram Greimas e Courtés (2008, p. 173), relacionados ao inacabamento do mundo. O esboroamento de fronteiras articulado a desdobramentos da sintaxe discursiva pode servir ao delineamento do corpo do ator da enunciação e pode ser examinado no âmbito da literatura como um vetor de estilo. 


\section{Um conto}

As macroembragens que, do lugar da sintaxe discursiva, comprovam que a veridicção se articula na dependência do "lugar frágil", que é o discurso, como diz Greimas (1983, p. 105), podem ser depreendidas de um conto de Mário de Andrade (2011) , Frederico Paciência . O caso de amor entrevisto sutilmente na relação de amizade entre dois jovens, Frederico Paciência e o narrador-participante da história narrada, encontra, no último parágrafo do texto, o desfecho, enquanto conversam os interlocutores com vistas a finalizar um comentário anteriormente feito pelo narrador. Frederico é então lembrado num momento de irritação sua diante de uma "pequena" que o teria abraçado durante um baile. O narrador lembra-se do que dissera para Frederico, "sem intenção de trocadilho", naquela ocasião. Entretanto, no comentário feito, ao reconstruir a experiência vivida, o narrador funda-a no esboroamento da referencialização enunciativa:

- Paciência, Rico.

- Paciência me chamo eu!

Não guardei este detalhe para o fim, pra tirar nenhum efeito literário, não. Desde o princípio que estou com ele para contar, mas não achei canto adequado. Então pus aqui porque, não sei... essa confusão com a palavra "paciência" sempre me doeu malestarentamente. Me queima feito uma caçoada, uma alegoria, uma assombração insatisfeita (ANDRADE, 2011, p. 118).

Entre o silêncio prolongado pelo uso das reticências, o que o desobriga de ater-se a um simulacro de "transparência" ou de parecer dizer tudo o que se pretende, e a maleabilidade sígnica lexicalizada no neologismo malestarentamente, o narrador instala-se na narrativa de modo a poder contribuir para o corpo do ator da enunciação como afeito a um mundo ao revés. Joga então com a temporalidade da narração (o agora do ato de enunciar trazido à luz nos comentários metadiscursivos) e o momento relativo ao fato instalado no passado, o encontro entre os dois adolescentes. $\mathrm{O}$ narrado diz respeito ao tempo de então (sistema temporal enuncivo de pretérito). Desse modo, enquanto são preenchidos os "vazios" da história com explicações, borram-se os limites entre o agora da narração e o então do diálogo rememorado. Na mobilidade das fronteiras discursivas, a presença torna-se mais viva e a memória mais sensível, com ares de coisa que invade o sujeito à revelia da vontade dele. Um sujeito afetado pelo mundo, isto é, um sujeito da percepção toma corpo, justamente por meio do borrão entre os limites das temporalidades discursivas.

O sujeito que sente pode ser lembrado como aquele do pâtir (sofrer). A denominação extraída da língua francesa, articulada à origem etimológica da palavra paixão, remete ao sujeito que "aparece como um paciente", como diz Greimas (1983 ), ao distin- 
guir "o sujeito do fazer, que se apresenta como um agente, como um elemento ativo, que acumula em si todas as potencialidades do fazer" (p. 97 ), e o sujeito de estado. O último, segundo esse estudo, "recolhe, passivo, todas as excitações do mundo, inscritas nos objetos que o cercam" (GREIMAS, 1983, p. 97 ). Aí o sujeito, não priorizado conforme uma competência que o prepara para determinada ação ou performance, é examinado em sua existência modal, o que se confina com o corpo sensível.

O sensível é cotejado pelos desdobramentos contemporâneos da semiótica, em especial pelos estudos tensivos desenvolvidos por Zilberberg (2011), que tratam as relações tensivas como as que sustentam, de um lado, a dimensão da intensidade articulada pelo andamento (velocidade) e pela tonicidade (força e impacto) da percepção, e de outro, a extensidade, lembrada como a que ancora o tempo como duração (breve ou longa) e o espaço como abertura ou fechamento - tudo a partir de sílabas tensivas: mais mais (na direção de um recrudescimento do que é percebido); menos mais (na direção de uma atenuação do que é percebido), e assim por diante.

No momento citado do conto, o narrador alonga-se em explicações e, como corpo, apresenta um olhar cifrado por uma desaceleração do que era extático: agora ele pode liberar-se das supostas ilusões de mímese e afundar-se na poiese, que é esse mundo tecido na linguagem, o que se viabiliza justamente por meio de recursos da sintaxe discursiva. É diferente o que acontece em outras passagens como esta, vinculada a um acontecimento ocorrido depois da aula:

Depois da aula, naquela pequena parte do caminho que fazíamos juntos até o largo da Sé, puxando assunto para os colegas, afinal acabei, bastante atrapalhado, lhe confessando que ele era meu "único" amigo. Frederico Paciência entreparou num espanto mudo, me olhando muito. Apressou o passo pra pegar minha dianteira pequena, eu numa comoção envergonhada, já nem sabendo de mim, aliviado em minha sinceridade. Chegara a esquina em que nos separávamos, paramos. Frederico Paciência estava maravilhoso, sujo do futebol, suado, corado, derramando vida (ANDRADE, 2011, p. 101).

O narrado aí evolui para uma modulação aumentativa (mais e mais emoção), até a percepção finalmente pôr a nu, no extremo da visão monopolizada pela recordação amorosa, a atratividade do objeto contemplado: "Frederico Paciência estava maravilhoso, sujo do futebol, suado, corado, derramando vida." A emoção provocada pelo objeto da visão, Frederico Paciência, mantém-se robustecida pela gradação crescente do sentido das figuras, que explodem no ato de derramar a vida. Além disso, não é convocada a decifração feita, pelo narrador, do próprio ato de narrar. Essa decifração, que se emparelha a uma inteligibilidade atuante, desaceleradora do impacto, como aconteceu na passagem do 
desfecho do conto, voltada para explicações feitas pelo narrador, faz a emoção atenuar-se, a percepção desacelerar-se, e o corpo minimizar-se em êxtase. Assim se cumpria, na passagem que aludia a Baudelaire, a macroembreagem discursiva, na relação com a tensão e a distensão, componentes da tensividade (ZILBERBERG, 2006). Ao nível tensivo, que se espraia ao longo de todo o processo de geração do sentido, não pode escapar a organização das pessoas discursivas.

Por conseguinte, enquanto a sintaxe e a semântica comprovam-se como compartimentos não fechados em si mesmos, a macroembreagem firma-se como condição para a emergência de um modo peculiar de reagir ao impacto emocional contido na própria lembrança. Na ambiência que discursiviza o caso vivido com Frederico Paciência, a macroembreagem identificada contribui para encerrar o conto por meio não de um recrudescimento dos "valores de impacto", mas de uma descendência e amenização de tais valores, possibilidades estas oferecidas pelo estudo feito por Zilberberg (2011, p. 92-93) sobre a correlação entre "valores de impacto" e "de universo". Em Frederico Paciência, o corpo do enunciador, tal como tratado pelo narrador no excerto que reproduz a macroembreagem, torna-se difuso o suficiente para que $o$ tempo-espaço da percepção se oriente na direção de uma "abertura" espacial e de um "repouso" da temporalidade, o que ratifica a "distensão" alcançada (ZILBERBERG, 2006, p. 147) na alternância com as tensões de outros encontros. Entre eles, emerge este, em que se narra um disfarce relativo ao fato de ambos estarem, no ambiente escolar, a manusear um livro sobre a história da prostituição na antiguidade:

Passamos o tempo das aulas disfarçando bem. Mas no largo da Sé, Frederico Paciência falou que hoje carecia ir já pra casa, ficando logo engasgadíssimo na mentira. Mas como eu o olhasse muito, um pouco distraído em observar como é que se mentia sem ter jeito, ele inda achou força pra esclarecer que precisava sair com a Mãe (ANDRADE, 2011, p. 103).

"Frederico Paciência falou que hoje carecia ir já pra casa". Encontramos aí uma neutralização entre duas expressões temporais, o advérbio hoje e a expressão naquele dia, com benefício do primeiro, que é elemento presentificador e que expressa concomitância ao ato de enunciar. Deparamo-nos então com uma embreagem temporal, o que dá indicação de um vetor de estilo como inclinação para borrar limites e diluir fronteiras. A função desempenhada por essa embreagem, no todo que compõe o conto, se não apresenta a mesma força de esboroamento da ilusão referencial da macroembreagem anteriormente citada, remete a uma orientação, a um devir ou a uma protensividade de um corpo inclinado ao lugar de limiar. 
Limiar e limite se alternam. Logo, nada impede que encontremos, ao longo do narrado, passagens que projetam uma inclinação ao fechamento do espaço da percepção, o que reforça uma orientação distinta daquela apresentada no desfecho do conto. São ocasiões em que se sobrelevam das cenas narradas sentimentos fortes, tal qual uma "tristeza quase sensual" (ANDRADE, 2011 , p. 108) vivida pelos dois jovens. É o caso da memória relativa ao enlevo daquela amizade, tão intimamente partilhada que os valores de impacto se recrudescem mutuamente, e o sujeito fica à mercê do que sobrevém a ele naquele tempo de então.

Nessas passagens, descolam-se momentaneamente da mobilidade as fronteiras que definem o corpo. Domina, na sintaxe discursiva, ao lado do sistema enuncivo de pretérito (aquele tempo de então), o sistema de projeção de pessoa, em que não se diluem os limites entre os níveis enunciativos, os quais tinham sido postos entre borrões de concomitância na macroembreagem comentada. O enunciador mantém-se como "destinador implícito da enunciação" , e o narrador, destinador "instalado no enunciado" (FIORIN, 1996, p. 65 ), mantém-se como voz delegada - para que se componha o ator que conta a própria história, sem que o agora do ato de enunciar invada o passado rememorado e sem que se tornem simultâneas a temporalidade da narração e a do narrado, para que a oposição entre elas se neutralize.

Frederico Paciência recuou, derrubando a cadeira. O barulho facilitou nosso fragor interno, ele avançou, me abraçou com ansiedade, me beijou com amargura, me beijou na cara em cheio dolorosamente. Mas logo nos assustou a sensação de condenados que explodiu, nos separamos conscientes. Nos olhamos olho no olho e saiu o riso que nos acalmou. Estávamos verdadeiros e bastantes ativos na verdade escolhida. Estávamos nos amando de amigo outra vez; estávamos nos desejando, exaltantes no ardor, mas decididos, fortíssimos, sadios (ANDRADE, 2011, p. 109).

O corpo do narrador, aí, embora dilacerado por contradições, mantém-se preso ao impacto sensível. Enquanto se intensifica a percepção de um afeto como objeto concomitantemente "desejável" e "nocivo", possibilidades lembradas por Greimas (1983, p. 99) ao estudar a modalização do objeto, ascende em intensidade a emoção do vivido, este que se mantém como o que é rememorado e fisgado do passado, no qual habita. O passado não invade o presente. Mas, como estilo é um modo recorrente de dizer, que remete a um modo próprio de ser, notamos que é retomada a mobilidade das fronteiras na definição do corpo por meio desta outra passagem, em que recobra seu lugar a macroembreagem, com teor equivalente ao da anteriormente vista:

Era uma ventura incontável esse encontro dominical, quanta franqueza, quanto abandono, quanto passado nos enobrecendo, nos aprofundando e era como uma carícia longa, velha, 
entediada. Vivíamos por vezes meia hora sem uma palavra, mas em nossos espíritos, nossas almas entreconhecidas se entendiam e se irmanavam com silêncio vegetal.

Estou lutando desde o princípio destas explicações sobre a desagregação de nossa amizade, contra uma razão que me pareceu inventada enquanto escrevia, para sutilizar psicologicamente o conto. Mas agora não resisto mais. Está me parecendo que entre as causas mais insabidas, tinha também uma espécie de despeito desprezador um pelo outro (ANDRADE, 2011, p. 111-112).

Não à toa, uma sinestesia junta o que é da ordem da audição (silêncio) e o que é de outra natureza, tátil (vegetal), enquanto a memória se deixa arrebatar pelas cenas de "ventura incontável". No primeiro parágrafo do excerto, o êxtase segura a união daqueles corpos como percepção, num "tempo remissivo", o tempo da "cronia" e da "passeificação", como diz Zilberberg (1986, p. 235) no estudo feito sobre a temporalidade, a qual concebemos como relativa à duração da percepção. Enquanto isso, nesse excerto, sintaticamente desdobra-se o sistema enuncivo de pretérito, por meio dos verbos conjugados no pretérito imperfeito: era (duas ocorrências); vivíamos; entendiam; irmanávamos, instaurados todos na concomitância com o momento do acontecimento narrado, o encontro dominical. O mundo está no lugar. Ainda, já que os pretéritos imperfeitos remetem ao mesmo momento de referência, firma-se aí um "efeito de sentido de estaticidade" (FIORIN, 2003, p. 171), de que se beneficia o modo de constituir o corpo nesse segmento textual. Por sua vez, na percepção, o que supõe relações tensivas, o tempo-espaço, nesse primeiro parágrafo, delineia-se segundo um espaço fechado, próprio à retenção do tempo vivido.

Mas o segundo parágrafo traz à luz a alternância relativa ao estado de contenção e de retenção. Esse procedimento ampara o ritmo que funda o corpo, que acaba por definir-se como projetado na ordem da mobilidade. A macroembreagem novamente promove a simultaneidade entre a temporalidade da narração e a do narrado, o que retoma a neutralização da oposição entre elas. Uma vez mais são desfeitos os limites entre o agora do ato de enunciar (a temporalidade da narração), em que o narrador dá explicações sobre o ato de narrar, e aquele tempo concomitante aos encontros dominicais.

O encontro dominical, como marco referencial pretérito, ampara-se em outros marcos referenciais pretéritos que sustentam o narrado, como se vê na alusão feita ao período escolar envolvido: "Foi no ginásio... Éramos de idade parecida, ele pouco mais velho que eu, quatorze anos" (ANDRADE, 2011 p. 99). Se aí se mantém estável o subsistema temporal da anterioridade, as imprevisibilidades irromperão iterativamente ao longo do conto, o que favorece a diluição das fronteiras em formulações como estas: "Agora falávamos insistentemente da nossa 'amizade eterna" - em que o 
uso do advérbio agora decorre de uma neutralização estabelecida com seu oposto, a expressão adverbial naqueles dias ou qualquer outra equivalente aos tempos do ginásio.

\section{Notas finais}

Landowski (1997), ao referir-se à ruptura provocada por um acontecimento perturbador em relação a alguma normalidade, alude a uma forma de "acidente" (p. 232), para o que faz remissão ao que expõe Greimas (2002) na obra Da imperfeição como o que acontece entre fraturas e escapatórias estabelecidas em relação a uma cotidianidade baça. Pelas indicações oferecidas pelo breve exame feito do conto Frederico Paciência, a ruptura lembrada por Landowski está na presença de Rico (Frederico), como ator que toma conta do mundo percebido pelo narrador, já na semantização temático-figurativa do mundo rememorado, da qual despontam papéis temáticos dos atores-amantes: "nos amávamos pelo que éramos, tal como éramos, desprendidamente, gratuitamente, sem o instinto imperialista de condicionar o comportamento a ficções de nossa inteira fabricação" (ANDRADE, 2011, p. 113). Mas o "acidente", como fratura do que é ordinário, está também na instabilidade provocada pela instalação peculiar do narrador na narrativa, quando ele joga com a temporalidade da narração e a do narrado, preenchendo os "vazios" da história com explicações, o que leva ao colapso das fronteiras entre os níveis enunciativos.

"Acidente", fratura do que é ordinário e colapso de fronteiras do corpo - abeiramo-nos da temporalidade que compõe o corpo como percepção. Lembramos então que essa temporalidade pode ainda ser contemplada segundo modulações que incluem gestos relativos a um fazer remissivo e a um fazer emissivo (ZILBERBERG, 2006). Se, a um tempo emissivo corresponde uma temporalidade da "mnésia", "lugar de simultaneizações e que traz à luz a presentificação" (ZILBERBERG, 1986, p. 234), confirma-se no conto a recorrência da presentificação da percepção. Isso acontece por meio das embreagens destacadas, isto é, por meio das neutralizações que acabaram por beneficiar o termo indicativo do presente diante do termo indicativo do passado, assim obliterado. A isso se junta a macroembreagem de pessoa, mantida sua função específica.

Desse modo são oferecidas indicações de como o sensível rege peculiarmente o inteligível no todo que compõe o conto, enquanto se processa a constituição de um corpo afeito às fronteiras móveis. Greimas (2002) fala em "superação de fronteiras" (p. 34), ao identificar o objeto estético com a fratura que, à moda de um relâmpago, é provocada ao longo de certa continuidade. O jovem Frederico Paciência, como ator que encarna a memória vivida e sentida, firma-se conforme essa fratura que, do êxtase oscilante entre o ir-e-vir da emoção, corrobora o corpo do ator da enunciação como protensividade e devir, enquanto se confirmam as fronteiras móveis como vetores de um estilo. 
A emergência das explicações no interior das macroembreagens de pessoa, registradas pelo narrador como desconstrução da própria arquitetura da escrita, não é restrita, portanto, a um fato isolado da sintaxe discursiva. As explicações constitutivas da macroembreagem de pessoa estão regidas por determinado ritmo tensivo, para que, em meio à neutralização de fronteiras temporais fincadas no nível discursivo, aquela "amizade" entre os dois jovens acabe por expressar a tensão relativa a uma apreensão estética, desenvolvida pelo sujeito-no-mundo.

De um lado, confirma-se o êxtase concentrado na relação entre os dois jovens e na presença de Rico para o narrador extasiado, o que remete ao guizzo lembrado por Greimas (2002): "um termo que designa o tremeluzir do pequeno peixe saltando da água, como um raio argênteo e brilhante, que, em um instante, reúne o cintilar da luz com a umidade da água". (p. 35) De outro lado e numa alternância rítmica, confirma-se a desaceleração dos valores do impacto, para o que desempenha função própria a macroembreagem de pessoa, ao borrar os contornos entre o ato de narrar e o próprio narrado. As fronteiras móveis na definição do corpo podem, portanto, ser examinadas tanto sob o viés discursivo como sob o viés tensivo da semiótica, esta que é um projeto único firmado como teoria da significação.

\begin{abstract}
We shall discuss the discursive, enunciating subject, who is assumed from the enunciate built by him, in which this man, as style, is designed on the basis of a body, a voice, a tone of voice, and a character. This body will be conceived especially as perception, which in its turn, is seen as semiosis, and will be considered as emerging from the relation expression/content of the texts. Thus, this subject, who experiences the world as impact and emotion, will emerge from the texts. In order to achieve this, first we will go through a reflection within the discursive syntax, where we shall establish the theoretical assumptions about the enunciation and the act of making sense and then we will examine the boundaries to the constitution of the body of the actor: the enunciating subject firmed in the role of producer of his own texts. These boundaries will be covered in their mobility, while mechanisms that promote the unraveling of the referential illusion will be brought to light, especially with regard to the merger of the temporalities of the enunciate and the enunciation in the constitution of the category of person. This
\end{abstract}


mobility is also contemplated according to a time-space of perception, for which we will examine the movements of opening of the space, resting of the time and distension of the body, which is bound to the dynamics established between the tensions of what is continuous and what is discontinuous in the perception.

Keywords: body; style; discourse; tension.

\section{REFERÊNCIAS}

ANDRADE, M. Contos Novos. Rio de Janeiro: Nova Fronteira, 2011. BARROS, D. L. P. de. Teoria do discurso: fundamentos semióticos. São Paulo: Atual, 1988.

BENVENISTE, E. Problemas de Linguística Geral I. Trad. Maria da Glória Novak e Maria Luisa Neri. 4. ed. Campinas: Pontes, 1995. FIORIN, J. L. Linguagem e ideologia. São Paulo: Ática, 1988. . As astúcias da enunciação. São Paulo: Ática, 1996.

GREIMAS, A. J. Du sens II. Essais sémiotiques. Paris: Éditions du Seuil, 1983.

. Maupassant a semiótica do texto: exercícios práticos. Trad. Teresinha O. Michels et al. Florianópolis: Editora da UFSC, 1993. . Da imperfeição. Trad. Ana Claudia de Oliveira. São Paulo: Hacker Editores, 2002.

GREIMAS, A. J.; COURTÉS, J. Sémiotique. Dictionnaire raisonné de la théorie du langage. Paris: Hachette, 1986, Tome 2.

. Dicionário de Semiótica. Trad. Alceu Dias Lima et al. São Paulo: Contexto, 2008.

HJELMSLEV, L. Prolegômenos a uma teoria da linguagem. 2. ed. Trad. J. Teixeira Coelho Neto. São Paulo: Perspectiva, 2003.

LANDOWSKI, E. Le sémioticien et son double. In: LANDOWSKI, E. (direction). Lire Greimas. Limoges: Presses Universitaires de Limoges, 1997, p. 229 - 255.

ZILBERBERG, C. Temporalisation. In: GREIMAS, A. J;; COURTÉS, J. Sémiotique. Dictionnaire Raisonné de la théorie du langage. Tome 2. Paris: Hachette, 1986, p. 233 - 235.

Razão e poética do sentido. Trad. Ivã Carlos Lopes; Luiz Tatit e Waldir Beividas. São Paulo: Edusp, 2006.

. Elementos de semiótica tensiva. Trad. Ivã Carlos Lopes; Luiz Tatit e Waldir Beividas. São Paulo: Ateliê Editorial, 2011. 